\title{
Hepatoprotective Effect of Solanum melongena/Eggplant against Acute Hepatitis
}

\author{
Nabhan Komara ${ }^{1}$, Herri S. Sastramihardja ${ }^{2}$, Afiati $^{3}$ \\ ${ }^{1}$ Faculty of Medicine, Universitas Padjadjaran, ${ }^{2}$ Department of Pharmacology and Therapy, \\ Faculty of Medicine, Universitas Padjadjaran, ${ }^{3}$ Department of Pathology Anatomy, Faculty of \\ Medicine, Universitas Padjadjaran/Dr. Hasan Sadikin General Hospital, Bandung
}

\begin{abstract}
Background: Hepatitis is a liver inflammation that can be acute or chronic and may cause damage to hepatocytes such as necrosis. Hepatocyte necrosis can be inhibited by antioxidants such as flavonoids found in Solanum melongena fruit. This study aimed to determine the hepatoprotective effect of Solanum melongena fruit infusion to inhibit hepatocytes damage in $\mathrm{CCl}_{4}$-induced rats.

Methods: Twenty five male Wistar rats were randomly divided into five groups, and adapted for 7 days before the experimental study. Negative and positive groups were given aquadest, Group III-V were given Solanum melongena fruit infusion containing 1.125 grams, 2.25 grams and 4.5 grams orally for 9 days. At the 9 th day, all rats were induced by $8 \mathrm{~mL} / \mathrm{kgBW}$ of $10 \% \mathrm{CCl} 4$ in paraffin, except for the negative group. Rats were sacrificed on the 11 th day, and liver biopsy preparations were made. Hepatocyte necrosis was counted and was analyzed by Kruskal-Wallis test and Mann-Whitney test.

Results: The study showed that the percentage of necrotic hepatocytes in group III, IV a nd V were lower than in the positive group. Using Mann-Whitney test, there were significant differences in negative group, group III, and group V $(\mathrm{p}<0.05)$. Meanwhile, unsignificant difference was seen between the positive group and group IV ( $>0.05)$. Kruskal-Wallis test showed that there weresignificantly differences among groups $(\mathrm{p}<0.05)$.

Conclusions: Solanum melongena fruit infusion has hepatoprotective effects against acute hepatitis in rat model histopathologically.
\end{abstract}

Key words: $\mathrm{CCl}_{4}$, flavonoids, hepatocyte, necrosis, Solanum melongena

\section{Introduction}

Hepatitis is an inflammatory condition of the liver. Two billion people have been infected by hepatitis B virus around the world and about 350 million people are at risk to have cirrhosis, liver failure and liver cancer. Moreover, hepatitis causes 1 million death each year. ${ }^{1}$ Hepatitis can be acute or chronic. It is called acute hepatitis if less than 6 months, and chronic hepatitis if it is more than 6 months. Hepatitis is also classified by the causes, such as hepatitis virus infection, autoimmune hepatitis, and hepatitis due to chemical or hepatotoxicity, which one of agent toxicity is carbon tetrachloride. ${ }^{2,3}$

Carbon tetrachloride $\left(\mathrm{CCl}_{4}\right)$ is a synthetic chemical compound that can be converted to free radical compounds that are not stable and can cause damage to the liver. The damage of the liver progresses rapidly can be either degeneration or necrosis of hepatocyte. ${ }^{3}$ Rubinstein and Suja et al. in Orhan et al. ${ }^{4}$ reported that the use of $\mathrm{CCl}_{4}$ inducing hepatotoxicity model is frequently conducted to investigate hepatoprotective drugs effect and plant extract, because the present of liver damage is similar to acute viral hepatitis.

Solanum melongena L (Solanaceae)/ Eggplant is a common subtropic and tropic vegetable, and consumed throughout the world. It is known to contain phenolic and flavonoids substances, which have antioxidant activity. ${ }^{5,6}$ Cao et al. in Akanitapichat et al. ${ }^{5}$ reported that the whole eggplant fruits possess antioxidant activities and are ranked among the top 10 vegetables in terms of antioxidant capacity. Nasunin, an anthocyanin isolated from the peel of purple eggplant fruit, is one phenolic compound implicated in both inhibition of hydroxyl radical generation and

Correspondence: Nabhan Komara, Faculty of Medicine, Universitas Padjadjaran, Jalan Raya Bandung-Sumedang Km.21, Jatinangor, Sumedang, Indonesia, Phone: +6285220095758 Email: nabhankomara@yahoo.com 
superoxide scavenging activity. ${ }^{5}$

The study aimed to determine the hepatoprotective effect of Solanum melongena to inhibit hepatocytes damage in CCl4-induced rats

\section{Methods}

An experimental study was conducted at Animal Laboratory of Department of Pharmacology and Therapy in Dr. Hasan Sadikin General Hospital Bandung during the period of September to October 2012. Solanum melongena fruits were procured from Lembang, Bandung, and were botanically identified at the Herbarium Jatinangor, Universitas Padjadjaran.

Twenty five healthy male Wistar rats (2-3 months old) weighing 150-250 gram were used as subjects. All rats were procured from Pusat Antar Universitas, Institut Teknologi Bandung; and were adapted in homogenous temperature and dark-light cycle for 7 days with an access to food and drink. The procedure was conducted in accordance with Russel and Burch's principle of experimental ethics : reduction, refinement, and replacement. ${ }^{7}$

Solanum melongena fruit infusion was prepared from sliced Solanum melongena fruit weighing according to dosage and 100 $\mathrm{mL}$ of water for every treatment group. Doses were obtained from Paget and Barnes's table conversion, and were made to $1 / 2,1$ and 2 times dosage. ${ }^{8}$ Mixed raw material was heated in an infusion pan for 15 minutes after the temperature reached $90^{\circ} \mathrm{C}$ and stirred every 5 minutes. Furthermore, the mixture was filtered using flanel fabric into measuring cup to produce infusion. If the infusion did not reach $100 \mathrm{~mL}$, extra boiling water was added to the infusion, stirred for one minute and then filtered again into the measuring cup until it reached the required volume.

Negative and positive groups were given aquades, group III-V were given Solanum melongena fruit infusion with a row that contained 1.125 grams, 2.25 grams and 4.5 grams orally for 9 days every morning. At afternoon of 9th day, all rats were induced $8 \mathrm{ml} / \mathrm{kg}$ of $10 \%$ CCl4 in paraffin, except negative group. Rats were sacrificed on 11th day using ketamine hydrochloride 0.4 $\mathrm{mL}$. After laparotomy, blood in rat liver was drained by physiological saline through the left ventricle. The liver was taken and put into formalin solution then cut into size of $1 \mathrm{~cm} \times 0.5 \mathrm{~cm} \times 0.5 \mathrm{~cm}$ and the liver chunks were made into paraffin block. The liver was sliced with thickness of $5 \mu \mathrm{m}$ and stained by haematoxylin-eosin. Hepatocyte necrosis in each group was counted and calculated into percentage value by comparing the amount of hepatocyte necrosis with amount of normal hepatocyte in the negative group. Data were statistically analyzed using Kruskal-Wallis and Mann-Whitney non-parametric tests. ${ }^{9}$

\section{Results}

Histopathological appearance of liver biopsy can be seen in Figure 1. The negative group showed hepatocytes arranged radially surrounded the central vein. Hepatocytes looked good with round nuclei and basophils, homogeneous cytoplasm, clear cell borders, indicating that liver tissue was still in normal circumstances, although found a few hepatocytes that underwent necrosis. The positive group showed a defect in hepatictissue. Hepatocyte appeared unstructured radially, with abundant infiltration of inflammatory cells such as lymphocytes in the portal area (zone 1) and extends toward the central vein. There were found many degeneration cells such as ballooning degeneration and acidophilic degeneration. Cells undergoing necrosis were found in almost all zones, with the worst damage in zone 1 . However, normal hepatocytes could be still found in zones 2 and 3 .

The group III, IV and V showed a defect in hepatic tissue but not as bad as in the positive group. Hepatocyte appeared unstructured radially but not as bad as in the positive group, with a few of infiltrations of inflammatory cells such as lymphocytes in the portal area (zone 1 ). There were rarely found degeneration cells either ballooning degeneration or acidophilic degeneration. Cells undergoing necrosis were found in zone 1, and normal hepatocytes were more common than in the positive group.

The number and percentage of necrotic hepatocyte in each group can be seen in Table 1. The negative group had the fewest necrotic hepatocyte $(1.27 \%)$. Meanwhile, the most necrotic hepatocyte were seen in positive group (37.26\%). All groups given Solanum melongena fruit infusion in 9 days before induction by $\mathrm{CCl}_{4}$ had necrotic hepatocytes fewer than positive group.

This result showed that Solanum melongena fruit infusion provided protection for hepatocyte against further damage, or in other word it had hepatoprotective effect in $\mathrm{CCl}_{4}$-induced rats.

To determine hepatoprotective effect between groups, Mann-Whitney test was exerted and each group was compared to the 


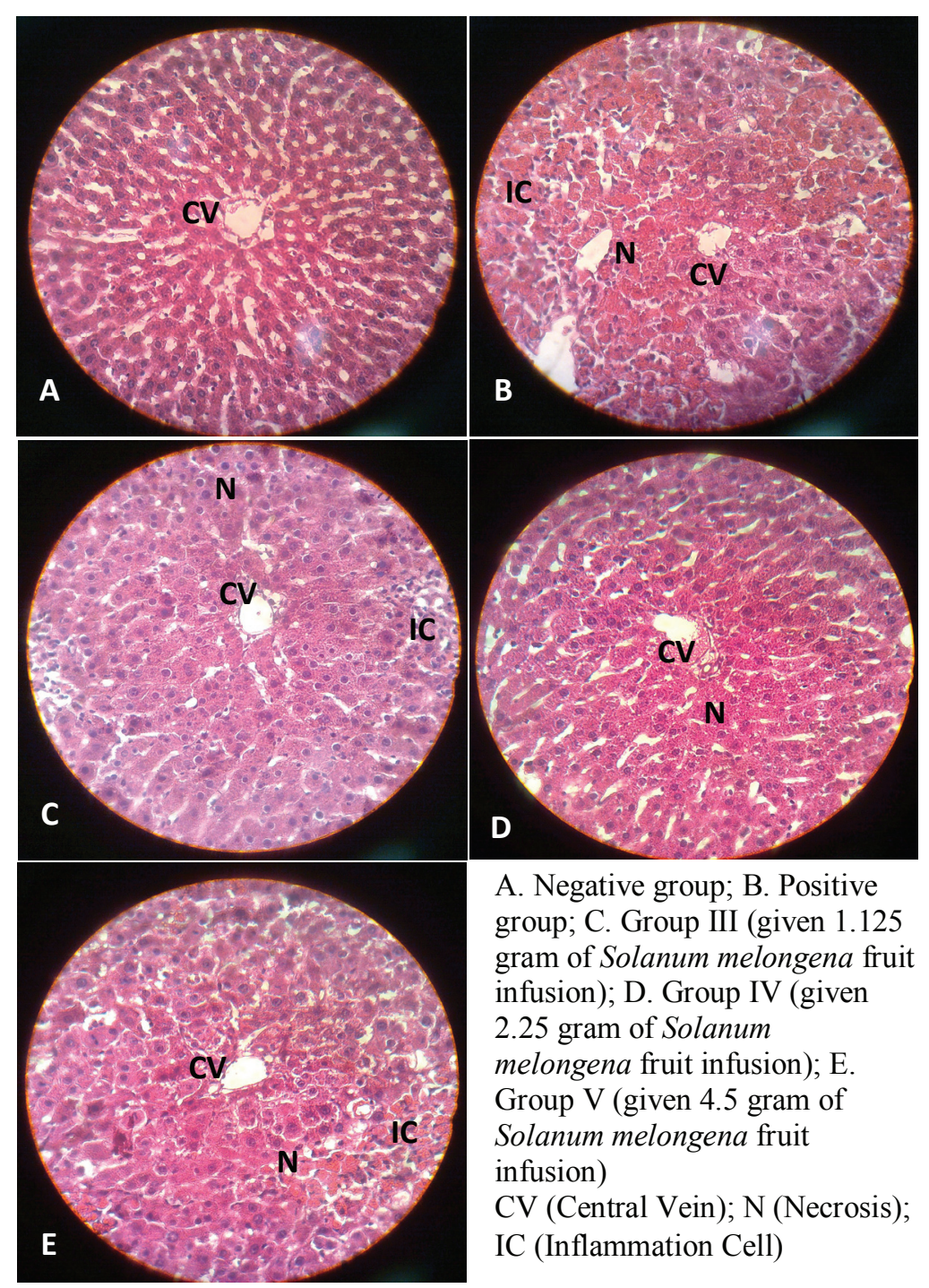

Figure 1 Histopathology of liver biopsy with 400x magnification

positive group. The result of this test were significant different in the negative group, the group given 1.125 gram, and 4.5 gram of Solanum melongena fruit infusion with $\mathrm{p}=0.005 \quad(\mathrm{p}<0.05)$. Meanwhile, insignificant difference was seen between the positive group and the group who given 2.25 gram of Solanum melongena fruit infusion with $\mathrm{p}=0.058(\mathrm{p}>0.05)$.

To determine the significance effect, Kruskal-Wallis test was exerted, and the result was significantly with $\mathrm{p}=0.002(\mathrm{p}<0.05)$.

\section{Discussion}

In this study, based on comparison with normal cells in the negative group, it was found that in the positive group which is only induced by $\mathrm{CCl}_{4}$ showed that the amount of hepatocyte necrosis is $37.26 \%$. $\mathrm{CCl}_{4}$ is a chemical activated by cytochrome $\mathrm{p} 450$ to form free radicals. Initially, $\mathrm{CCl}_{4}$ converted to trichloromethyl radical $\left(\mathrm{CCl}_{-}-\right)$will form trichloromethylperoxy radical $\left(\mathrm{CCl}_{3} \mathrm{O}_{-}-\right)$, which can cause lipid peroxidation if it reacts with oxygen. Although lipid peroxidation caused by $\mathrm{CCl}_{3} \mathrm{O}_{2}$ - is more dominant, $\mathrm{CCl}_{3}-$ can also directly cause lipid peroxidation by binding with fat. Lipid peroxidation is the main cause of tissue damage, including inflammation. In this study, liver tissue damage was found in accordance with a previous study by Brattin and Shi which stated that $\mathrm{CCl}_{4}$ can cause damage to hepatocytes. ${ }^{10,11}$ Based on the theory of literature and 
Table 1 The percentage of necrotic hepatocyte in each group

\begin{tabular}{cccccc}
\hline & Group I & Group 2 & Group 3 & Group 4 & Group 5 \\
& $\%$ & $\%$ & $\%$ & $\%$ & $\%$ \\
\hline Rat 1 & 1,29 & 39,08 & 24,50 & 31,98 & 17,16 \\
Rat 2 & 1,33 & 37,79 & 22,17 & 16,08 & 24,10 \\
Rat 3 & 1,18 & 42,55 & 31,45 & 23,50 & 16,62 \\
Rat 4 & 1,22 & 33,56 & 26,83 & 86,71 & 22,06 \\
Rat 5 & 1,33 & 33,35 & 16,44 & 14,61 & 30,59 \\
Mean & $\mathbf{1 , 2 7}$ & $\mathbf{3 7 , 2 6}$ & $\mathbf{2 4 , 2 8}$ & $\mathbf{3 4 , 5 8}$ & $\mathbf{2 2 , 1 1}$ \\
\hline
\end{tabular}

I = Negative Group; II = Positive Group; III = Dosage $1 \frac{1}{2} \mathrm{x}$; IV = Dosage $1 \mathrm{x}$; V = Dosage $2 \mathrm{x}$.

previous study by Shi and Badria, liver tissue damage induced by $\mathrm{CCl}_{4}$ naturally suggests that hepatocyte necrosis is more abundant in zone 3 (centrilobular necrosis), because in zone 3 there are many cytochrome $\mathrm{p} 450$ that activate $\mathrm{CCl}_{4}$ into $\mathrm{CCl}_{3}$ - which are free radicals. In this study, hepatocytes that undergo necrosis are more common in zone 1 (periportal necrosis). ${ }^{11,12}$ In addition to hepatocyte damage caused by $\mathrm{CCl}_{3}$ - which is attached directly to fat causing lipid peroxidation, necrosis can also be caused by the $\mathrm{CCl}_{3} \mathrm{O}_{2}$ - which is a product of a reaction between $\mathrm{CCl}_{3}$ - and oxygen. $\mathrm{CCl}_{3} \mathrm{O}_{2}$ has a more reactive form and predominantly causes lipid peroxidation. ${ }^{3}$ Zone 1 is the richest zone with oxygen, therefore reaction of $\mathrm{CCl}_{3}$ - with oxygen to form $\mathrm{CCl}_{3} \mathrm{O}_{2}$ - is more common in this zone. Thus, it is possible for more necrosis in zone 1 as found in this study. It is also found in another study by Domitrovic (2009) that the results showed the presence of liver tissue damage in zone $1 .^{13}$

Cells that suffered from damage caused by unstable molecules such as free radicals can be protected by a compound called antioxidants. The antioxidants can slow or prevent the formation of free radical oxidation. One of the antioxidants contained in Solanum melongena fruit is flavonoids. Flavonoids will give electrons to $\mathrm{CCl}_{3}{ }^{-}$, thus prevent the formation of $\mathrm{CCl}_{3} \mathrm{O}_{2}$ - and prevent covalent bonds with fat. Therefore, the process of lipid peroxidation can be inhibited, so there is no tissue damage to the liver.14 In this study, the groups that were given Solanum melongena fruit infusion, which are group III (24.28\%), group IV (34.58\%), and group V (22.11\%) have fewer hepatocyte necrosis compared to the positive group which has more necrosis (37.26\%). This is consistent with the results of the study by Akanitapichat which showed that the Solanum melongena fruit has antioxidant and hepatoprotective activities. Another study by Arhoghro also showed that flavonoids have hepatoprotective activities although not from the Solanum melongena fruit. ${ }^{15}$

Based on these results, it can be concluded that administration of Solanum melongena fruit infusion in all rat groups III and V can provide hepatoprotective effect against $\mathrm{CCl}_{4}^{-}$ induced acute hepatitis. In group IV, there is a rat with $86.71 \%$ necrosis which has more necrosis than the mean in the positive group (37.26\%), although the mean necrosis in group IV (34.58\%) is still below the mean of positive group. This could happen because according to the theory, each rat has different level of immunity as well as different immunity of each individual human. Therefore, although this rat has given Solanum melongena fruit infusion which has hepatoprotective effect on other groups, hepatoprotective effect in this rat does not appear.

This study analyzed only one variety of eggplant, meanwhile there are many varieties that can be planted in Indonesia and frequently consumed by Indonesian people. Those varieties should be analyzed its hepatoprotective effect as well.

It concluded that Solanum melongena fruit infusion has hepatoprotective effects against acute hepatitis rat model.

\section{References}

1. Ministry of Health Republic of Indonesia. Saatnya lawan hepatitis. 2012 [Cited 2012 April 8]; Available from: http://www. depkes.go.id/index.php/berita/pressrelease/1557-saatnya-lawan-hepatitis. html.

2. Fauci AS, Braunwald E, Kasper DL, Hauser SL, Longo DL, Jameson JL, et al. Harrison's Principles of Internal Medicine. $18^{\text {th }}$ ed. New York: McGraw-Hill Medical; 2012. 
3. Hodgson E, editor. A Textbook of Modern Toxicology. ${ }^{\text {rd }}$ ed. New Jersey: John Wiley \& Sons, Inc.; 2004.

4. Hariana A. 812 Resep untuk mengobati 235 penyakit. $2^{\text {nd }}$ ed. Depok: Penebar Swadaya; 2005.

5. Akanitapichat P, Phraibung K, Nuchklang K, Prompitakkul S. Antioxidant and hepatoprotective activities of five eggplant varieties. Food Chem Toxicol. 2010;48(10):3017-21.

6. Tiwari A, Jadon RS, Tiwari P, Nayak S. Phytochemical investigation of crown of solanum melongena fruit. International Journal of Phytomedicine. 2009;1:9-11.

7. Hanafiah MJ. Etika kedokteran dan hukum kesehatan. $4^{\text {th }}$ ed. Jakarta: EGC; 2009.

8. Hashem MM, Atta AH, Arbid MS, Nada SA, Asaad GF. Immunological studies on Amaranth, Sunset Yellow and Curcumin as food colouring agent in albino rats. Food Chem Toxicol. 2010;48(6):1581-86.

9. Dahlan MS. Statistik untuk kedokteran dan kesehatan. $4^{\text {th }}$ ed. Jakarta: Salemba Medika; 2009.

10. Brattin WJ, Glende Jr EA, Recknagel RO. Pathological mechanisms in carbon tetrachloride hepatotoxicity. J Free Radic Biol Med. 1985;1(1):27-38.

11. Shi J, Aisaki K, Ikawa Y, Wake K. Evidence of hepatocyte apoptosis in rat liver after the administration of carbon tetrachloride. Am J Pathol. 1998;153(25):515-25.

12. Badria AF, El-Belbasi HI, Sobh MM, Badria FA. Parallelism study between biochemical, immunological and histochemical parameter of liver injury induced by carbon tetrachloride on rats. Journal of American Science. 2011;7(5):581-91.

13. Domitrovic R, Jakovac H, Tomac J, Sain I. Liver fibrosis in mice induced by carbon tetrachloride and its reversion by luteolin. Toxicol App Pharmacol. 2009;241(3):311-21.

14. Hamid AA, Aiyelaagbe 00, Usman LA, Ameen OM, Lawal A. Antioxidants: its medicinal and pharmacological applications. Afr J Pure App Chem. 2010;4(8):142-51.

15. Arhoghro EM, Ekpo Ke, Ibeh GO. Effect of aqueous extract of scent leaf (Ocimum gratissimum) on carbon tetrachloride (CCl4) liverdamage in albino Wister rats. Afr J Pharm Pharmacol. 2009;3(11):562-67. 